\title{
PEST - Analysis and SWOT - Analysis as the Most Important Tools to Strengthen the Competitive Advantages of Commercial Enterprises
}

\author{
Shabanova L.B. \\ Kazan Institute (branch), "Russian Economic University" named after, G.V. Plekhanov, Kazan, 420111, Russia \\ Ismagilova G.N. \\ Kazan Federal University, Institute of Management, Economics and Finance, Kazan, 420008, Russia \\ Salimov L.N. \\ Institute of Economics, Management \& Law (Russia, Kazan), Kazan, 420108, Russia
}

Akhmadeev M.G.

Kazan Institute (branch), "Russian Economic University" named after, G.V. Plekhanov, Kazan, 420111, Russia

\section{Doi:10.5901/mjss.2015.v6n3p705}

\section{Abstract}

Commercial enterprises operating in the regional market, forced to constantly monitor changes in the environment that have a direct impact on its business. To effectively analyze the external environment has developed special techniques, among which the most popular PEST - and SWOT - analysis. The results of this analysis can reveal not only the strengths but also weaknesses in the enterprise, as well as to identify the threat in the short term, to optimize the functioning of the enterprise and to strengthen its competitive position.

Keywords: PEST and SWOT - analysis, methods, competitive advantages, trade enterprises.

\section{Introduction}

Over the last 3-5 years in the city of Kazan, a large number of hypermarkets and supermarkets, which are large networks operating in many parts of the country. Barriers to entry into the market of food is not high, especially for large retail chains. This leads to increased competition, which entails a struggle for each customer, whose demands grow. In large towns (population over 500 thousand people), there are areas where there is a cluster of several grocery stores, each of which presents its range, its price level and level of service. Such a concentration of competitors is a huge threat to the enterprise entails the need for continuous monitoring of the activities of competitors. Methodology PEST- and SWOTanalysis provides the monitoring. Marketing analysis of enterprises in Russia, assessment of the role of consumer spending in ensuring the dynamics of the Russian economy, as well as study models the interaction of firms and components of the environment in Russia has a particular organization $[1,2,7]$.

\section{Method}

To analyze the internal and external environment of the enterprise is used PEST- and SWOT - analysis. PEST-analysis is a method of analysis of the key elements of the macro. This uncontrollable external conditions, which must adapt to the enterprise. SWOT - analysis allows us to distinguish 4 groups of factors that affect the activity of the company: strengths, weaknesses, opportunities and threats. Under present conditions, these methods are widely used [3-6].

\section{Result}

Table 1 shows the structure of PEST-analysis supermarket "Perekrestok". In the first column of the experts pointed out the specific events related to this factor, in the second - to assess the nature of their impact on the commercial enterprise. 
In the third column provides an estimate of the probability of occurrence of events, in the fourth - proposes specific actions to adapt to the supermarket factor (event).

Table 1. PEST-analysis supermarket "Perekrestok"

\begin{tabular}{|c|c|c|c|}
\hline $\begin{array}{l}\text { Events, trends associated with the } \\
\text { factor }\end{array}$ & $\begin{array}{l}\text { The nature of the } \\
\text { impact }\end{array}$ & $\begin{array}{c}\begin{array}{c}\text { Probability of occurrence } \\
\text { of events or trends }\end{array} \\
\end{array}$ & Program of action and reaction on this factor \\
\hline \multicolumn{4}{|c|}{ Political factors } \\
\hline $\begin{array}{l}\text { Election of the President of the } \\
\text { Republic of Tatarstan }\end{array}$ & + & $100 \%$ & $\begin{array}{l}\text { Adoption of strategic decisions be postponed } \\
\text { until the election. }\end{array}$ \\
\hline Adaptation to the WTO & + & $90 \%$ & $\begin{array}{l}\text { The gradual introduction of the CMK standards } \\
\text { in the production of its own products, service } \\
\text { system. }\end{array}$ \\
\hline $\begin{array}{l}\text { State regulation of competition in the } \\
\text { industry }\end{array}$ & + & $100 \%$ & $\begin{array}{l}\text { Save suppliers, to find a compromise in doing } \\
\text { business. }\end{array}$ \\
\hline Changes in legislation &,+- & $70 \%$ & $\begin{array}{l}\text { Tracking information regarding amendments to } \\
\text { the bills. Changes caused by Russia's WTO } \\
\text { accession. }\end{array}$ \\
\hline $\begin{array}{l}\text { Relationship supermarket with } \\
\text { authorities, both at the regional and } \\
\text { local level }\end{array}$ & + & $50 \%$ & $\begin{array}{l}\text { Sponsoring organization, charity events. } \\
\text { Creation of competitive jobs, paying taxes in the } \\
\text { budget. }\end{array}$ \\
\hline \multicolumn{4}{|c|}{ Economic factors } \\
\hline $\begin{array}{l}\text { The overall economic situation in the } \\
\text { region (lifting, stabilization, decline) }\end{array}$ & + & $100 \%$ & $\begin{array}{l}\text { Tracking: growth of industry, the investment } \\
\text { attractiveness of the region, the presence of } \\
\text { depressive regions. }\end{array}$ \\
\hline Inflation & + & $100 \%$ & $\begin{array}{l}\text { The price increase with an increase in inflation, } \\
\text { not of a speculative nature. }\end{array}$ \\
\hline $\begin{array}{l}\text { The dynamics of the CBR refinancing } \\
\text { rate }\end{array}$ & + & $100 \%$ & $\begin{array}{l}\text { Regular monitoring of the refinancing rate, which } \\
\text { affects the interest rate of the loan for legal } \\
\text { entities. The calculation of the discount factor. }\end{array}$ \\
\hline Unemployment rate & + & $100 \%$ & $\begin{array}{l}\text { Change the range according to the economic } \\
\text { situation in the region. }\end{array}$ \\
\hline \multicolumn{4}{|l|}{ Social factors } \\
\hline Changes in the structure of income & + & $100 \%$ & $\begin{array}{l}\text { With increasing purchasing power to expand its } \\
\text { range upwards, and vice versa, in case of } \\
\text { reduction of income buyers. }\end{array}$ \\
\hline The demographic situation & + & $100 \%$ & $\begin{array}{l}\text { Expand the range of baby food, as well as } \\
\text { increase network in the region. }\end{array}$ \\
\hline Social mobility & + & $70 \%$ & $\begin{array}{l}\text { With the increased mobility of increasing the } \\
\text { availability of semi-finished and finished } \\
\text { products in stock. }\end{array}$ \\
\hline Attitude to work and rest & + & $100 \%$ & $\begin{array}{l}\text { With the approaching holidays complementary } \\
\text { range of thematic products, to increase } \\
\text { purchases of products, to calculate the } \\
\text { possibility of reducing prices after the holidays to } \\
\text { avoid overstocking. }\end{array}$ \\
\hline $\begin{array}{l}\text { The level of education of the } \\
\text { population }\end{array}$ &,+- & $50 \%$ & $\begin{array}{l}\text { Compliance with the Law "On Protection of } \\
\text { Consumer Rights", increase the requirements for } \\
\text { purchased goods. }\end{array}$ \\
\hline \multicolumn{4}{|c|}{ Technological factors } \\
\hline The emergence of new products &,+- & $80 \%$ & $\begin{array}{l}\text { Identify and eliminate slow-moving products in } \\
\text { the range, to include the new. }\end{array}$ \\
\hline Trends in Science &,+- & $15 \%$ & $\begin{array}{l}\text { Tracking novelties commercial equipment in } \\
\text { order to optimize retail space in the store. }\end{array}$ \\
\hline $\begin{array}{l}\text { The development of e-commerce food } \\
\text { in the region (the Internet) }\end{array}$ &,+- & $20 \%$ & $\begin{array}{l}\text { The analysis of consumer preferences in how to } \\
\text { acquire food. }\end{array}$ \\
\hline $\begin{array}{l}\text { The emergence of new information } \\
\text { technologies }\end{array}$ &,+- & $50 \%$ & $\begin{array}{l}\text { The introduction to the work of the trade network } \\
\text { of information technologies that optimize the } \\
\text { transfer of information, management structure, } \\
\text { etc. }\end{array}$ \\
\hline
\end{tabular}

The table shows that the greatest impact on the supermarket "Perekrestok" have economic and social factors. 
To carry out the SWOT-analysis were drawn 7 experts (supermarket) who participated in the survey. As a tool for gathering information was used questionnaire. Experts were asked to evaluate all the factors that affect the activities of the organization on a 10-point scale.

Table 2. Questionnaire for SWOT - analysis

\begin{tabular}{|c|c|}
\hline Characteristics of the environment & point \\
\hline State regulation of the industry & 2,1 \\
\hline The level of market saturation & 3,4 \\
\hline Market growth & 5 \\
\hline The overall economic situation in the country & 5,5 \\
\hline Effect of inflation & 2 \\
\hline Changes in legislation and government policy & 5,2 \\
\hline The attitude of local authorities to the enterprise & 7,9 \\
\hline Payments to suppliers & 6,3 \\
\hline Jobs suppliers QMS & 1 \\
\hline Unemployment rate & 4,9 \\
\hline Income growth & 5,2 \\
\hline Attitude of the audience to contact us & 6,1 \\
\hline Barriers to entry to this market & 4,5 \\
\hline Increased competition in the industry & 3,7 \\
\hline The level of competition in the industry & 2,2 \\
\hline Opportunity to improve the quality of services / service competitors & 5,6 \\
\hline Policy competitors in the industry & 3,7 \\
\hline The concentration level of competition & 2,8 \\
\hline The ability of competitors to optimize the product range & 4,6 \\
\hline The growth of aggressive competitors & 4,3 \\
\hline Withdrawal from the market of some competitors & 6,3 \\
\hline The possibility of reducing the prices of competitors & 3,7 \\
\hline The emergence of new competitors & 6,2 \\
\hline The demographic situation & 6,3 \\
\hline Pricing policy on the market & 4,4 \\
\hline Stability of relationships with suppliers of products & 6,5 \\
\hline Possibility of increasing the prices of suppliers & 4,1 \\
\hline The possibility of replacing suppliers & 5,1 \\
\hline Characteristics of the internal environment & point \\
\hline Pricing flexibility & 4,1 \\
\hline Level of strategic planning & 6,5 \\
\hline Known trade network & 7,8 \\
\hline The level of scrutiny of competitors & 6,3 \\
\hline Settlements with personnel & 7,2 \\
\hline Total customer care & 6,2 \\
\hline Participation in the state (municipal) programs & 6,9 \\
\hline The duration of the trading network in the regional market & 4,1 \\
\hline Corporate Culture & 5,1 \\
\hline Wide range of products & 7,8 \\
\hline Profitability & 5,7 \\
\hline Attracting new partners & 4,8 \\
\hline The possibility of expanding sales network & 3,8 \\
\hline The share of sales & 3,6 \\
\hline Solvency & 6,7 \\
\hline Reputation trading network & 5,3 \\
\hline The overall financial condition of the company & 5,3 \\
\hline Working conditions & 7,3 \\
\hline Qualified staff & 7,2 \\
\hline Quality of services & 7,1 \\
\hline The effectiveness of the sales system & 5,4 \\
\hline
\end{tabular}




\begin{tabular}{|l|c|}
\hline The presence of SMC in the supermarket & 1 \\
\hline Enterprise readiness for the introduction of SMC & 2,5 \\
\hline Staffing system & 6,2 \\
\hline Organizational Structure & 7,5 \\
\hline Implementation of strategies & 4,7 \\
\hline Motivation system & 5 \\
\hline Further training of sales personnel & 5 \\
\hline Staff Development Technical Services & 5 \\
\hline Further training top-manager & 5,7 \\
\hline The system of sales promotion & 6,1 \\
\hline Location supermarket & 5,0 \\
\hline The level of organization of work with consumers & 5,9 \\
\hline Sales area & 7,3 \\
\hline The main commercial equipment & 7,4 \\
\hline Transactions with customers & 8,3 \\
\hline The level of receivables & 7,1 \\
\hline The level of accounts payable & 5 \\
\hline Outdoor Advertising & 7,1 \\
\hline Advertising in print & 5,6 \\
\hline System planning & 6,8 \\
\hline Control System Implementation & 5,4 \\
\hline Relations with public authorities & 6,4 \\
\hline
\end{tabular}

After grading, the scores for each indicator were averaged.

The attitude of local authorities and contact audiences to the trading network "Perekrestok" experts was estimated at 7 and 6.1 points respectively. Payments to suppliers were estimated at 6.3 points, as the company is cooperating with them for a long time. Suppliers are more interested in the customer. Therefore, such a measure as a change of supplier is not considered as a threat (5.1 points).

Products in stores "Perekrestok" comes from more than 900 suppliers, including 40 suppliers deliver the goods in supermarket own-brand network. Accordingly, the stability of relationships with suppliers experts estimated at 6.5 points.

Opportunity to improve the quality of services (Service) competitors, experts do not estimate a potent threat, this rate was estimated at 5.6 points.

The emergence of new competitors, experts do not predict (6.2 points). Furthermore, the tightening of trade rules in respect of the terms of sale of alcoholic beverages would reduce the number of small retail outlets, (implied kiosks, stalls) that are also indirect competitors supermarket "Perekrestok". The demographic situation in the country and in the region is favorable for the development of (6.3 points). Thus, the total score on the possibilities of the environment is 46.8 points.

Threats of the environment according to the experts a sufficient amount. Changes in legislation and government policy experts rated at 4.2 points. Such an indicator as "government regulation" experts attributed to threats external environment of the organization, and the average score was 2.1.

Despite population growth in the regions observed saturation of the market trading networks. Experts attributed "market saturation" threat to the environment (3.4 points).

Instability in exchange rates has been ranked among the threats of the external environment. Due to the fact that this indicator is characteristic of the daily volatility of the course that the sudden change in the direction of improving, and often so happens automatically entails a rise in the cost of goods, including food. As threats of the external environment experts attributed inflation (2 points), the unemployment rate (4.9 points), the policy of competitors in the industry (3.7 points), the ability to raise prices suppliers (4.1 points).

In a crisis, to understand and predict the actions of competitors is not possible, it's experts understand and appropriately evaluated (3.7 points).If a competitor decides depending on demand to optimize its range (4.6 points).

An enterprise Quality Management System is required today. Analyzing compliance supermarket "Perekrestok" of the certification system, experts predict the lowest score - 1. Total score on threats 51.4 points. In general, the external environment, we can conclude that the threat of more than opportunities.

Analyzing the internal environment of the supermarket, it was revealed the prevailing number of strengths. Level of strategic planning experts estimated at 6.5 points. The strategy of the company is flexible enough action.

In order to achieve its strategic goals supermarket monitors the prices of competitors. The level of scrutiny of 
competition is one of the primary tasks of daily management of the company and, therefore, is estimated at 6.3 points.

Praised indicator of outdoor advertising (8.1 points) and print advertising (5.6 points). Experts were highly appreciated by many of the indicators on the organization of labor in the supermarket "Perekrestok", so they are referred to the strengths of the trade network.

Further training top manager was estimated at 5.7 points. The indicator "training sales staff" and technical services experts was estimated at 5 points.

Location supermarket "Perekrestok" is rated at 5.0 points. Trading network tries to stick to the standard strategy in all regions, opening stores at the intersection of the main avenues of the city.

Large shopping area allows us to offer customers a broader range of products (ATM, terminal, etc.), which was noted by experts (7.3 points). Accounts receivable are estimated at 8.3 points. The level of quality of services - 7.1 points. The total number of points on the strengths of the supermarket "Perekrestok" was - 161.2 points.

The lowest scores were delivered by experts in the evaluation of indicators related to SMC. Products sold by a trading company, only $2 / 3$ of SMC. The main reason is the difficulty in implementing certification of the entire process. To implement this system requires well-trained staff.

Lowest score was set such indicators as investment policy (4 points.). Despite the fact that the supermarket "Perekrestok" from all retailers of Russian origin has the longest and successful credit history.

Since the level of prices of supermarket "Perekrestok" depends on the prices of suppliers to plan its pricing policy is difficult. Thus, pricing flexibility, refers to one of the weaknesses of commercial enterprise (4.1 points). The total number of points on the weaknesses of the supermarket "Perekrestok" is 28.6 points.

\section{Conclusion}

Thus, according to the results of the PEST-analysis are the most important economic and social factors, as they determine the purchasing power.

After analyzing the results of the SWOT - analysis, we can conclude that the external environment contains many threats, but at the same time, there are opportunities for the implementation of the strategic plans of the supermarket. According to experts, the benefits from the supermarket more than weaknesses: lack of SMC, the low share of sales, not enough flexibility in pricing, etc.

\section{References}

Bagautdinova N.G., Safiullin L.N., Badrtdinov N.N. The Role of Consumer Expenses in Ensuring Forward Dynamics of The Russian Economy // Mediterranean Journal of Social Sciences, 2014. Volume 5, № 12, pp. 43-48.

Bagautdinova N.G., Safiullin L.N., Minnahmetov R.R. Institutionalization of Firm Environment in Conditions of Growing Turbulence // Mediterranean Journal of Social Sciences, 2014. Volume 5, № 12, pp. 55-58.

Joseph Kim-Keung Ho. Formulation of a Systemic PEST Analysis for Strategic Analysis // European academic research, Vol. II, Issue 5, 2014, pp. 6478-6492.

Kurmanov N.A., Zhumanova B.K., Kirichok O.V. Business-Education in Kazakhstan: Opportunities and Development Strategy // World Applied Sciences Journal 21 (10), 2013, pp. 1495-1501.

Lokesh Vijayvargy, Prerna Jain. Strategic evaluation of distributed power generation technology: a sustainable approach // International Journal of Sustainable Development \& World Policy, 2014, 3(2), pp. 31-44.

Mohamed Syazwan Ab Talib, Abu Bakar Abdul Hamid, Mohd Hafiz Zulfakar, Ananda S. Jeeva. Halal Logistics PEST Analysis: The Malaysia Perspectives // Asian Social Science, Vol. 10, No. 14, 2014, pp. 119-131.

Safiullin M.R., Samigullin I.G., Safiullin L.N. Model of Management of Competitiveness of a Machine-building Complex // World Applied Sciences Journal 27 (Economics, Management and Finance), 2013, pp. 212-216.

Kirshin I.A. Modeling the long-term trend of accumulation of knowledge. Life Science Journal 2014; 11(6s): $482-486$.

Melnik A.N., Ermolaev K.A., Antonova N.V.Stages in Formalizing Energy Conservation and Efficiency Management in Industrial Enterprises// Mediterranean Journal of Social Sciences.- Vol.5, No12, (2014)-pp.173 - 176.

Gallyamova D. Kh. Development of Globalization in the Modern Economy // World Applied Sciences Journal 30 (9): 1160-1165, 2014

Glebova I.S., Yasnitskaya Ya.S., Maklakova N.V. Possibilities of "Smart City" Concept Implementing: Russia' s Cities Practice/l Mediterranean Journal of Social Sciences.- Vol.5, No12, (2014)-pp.129 - 133. 